\title{
Aplikasi Penyewaan Lapangan Futsal Berbasis Web
}

\author{
Muhammad Fatih Fahmi Fadhlurrahman ${ }^{1}$, Dwi Ade Handayani Capah ${ }^{2}$ \\ ${ }^{1,2}$ Program Studi Sistem Informasi, Universitas Mercu Buana \\ email: fatihfahmifadh@gmail.com ${ }^{1}$,dwi.ade@mercubuana.ac.id ${ }^{2}$
}

(Received: 18 Juli 2020/ Accepted: 1 September 2020 / Published Online: 20 Desember 2020)

\begin{abstract}
Abstrak
Di Indonesia terdapat salah satu olahraga yang terkenal yaitu Futsal. Oleh karena itu banyak terdapat usaha seperti tempat penyewaan lapangan futsal. Penyewaan lapangan futsal pada dasarnya masih bersifat manual, yaitu pelanggan datang ke lokasi futsal dan melakukan transaksi sewa lapangan. Penyewaan lapangan futsal yang manual ini memiliki masalah yaitu calon pelanggan tidak dapat secara langsung mengetahui jadwal kosong yang tersedia, hal itu menyebabkan ketika mereka sudah di lokasi namun tidak ada jadwal yang diinginkan maka mereka hanya membuang waktu saja. Tujuan dari penelitian ini adalah untuk mencari solusi agar dapat memecahkan masalah pada metode penyewaan lapangan futsal yang masih manual. Dengan dibuatnya sebuah aplikasi penyewaan lapangan futsal berbasis web yang diharapkan mampu mengatasi masalah tersebut. Aplikasi ini dibuat menggunakan metode pengembangan waterfall sehingga proses pembuatan aplikasi ini terdata secara urut dan rapih. Penelitian ini menghasilkan sebuah aplikasi penyewaan lapangan futsal berbasis web yang sudah diuji kelayakan nya menggunakan metode black box testing. Aplikasi ini menyediakan fitur sewa lapangan bagi para calon pelanggan, serta memudahkan dalam pengolahan data sewa lapangan dan data laporan keuangan bagi pemilik lapangan.
\end{abstract}

Kata kunci: Futsal, Jadwal, PHP, Sistem Informasi, Web.

\begin{abstract}
In Indonesia, there is one well-known sport, namely Futsal. Therefore, there are many businesses such as futsal court rental places. Basically, the futsal field rental is still manual, that is, customers come to the futsal location and make field rental transactions. This manual futsal court rental has a problem, namely that prospective customers cannot immediately find out the available empty schedule, this causes when they are already at the location but there is no desired schedule they are just wasting time. The purpose of this research is to find a solution in order to solve the problem in the manual futsal court rental method. With the creation of a web-based futsal court rental application that is expected to be able to solve this problem. This application was created using the waterfall development method so that the process of making this application is recorded in order and neat. This study produces a web-based futsal court rental application that has been tested for its feasibility using the black box testing method. This application provides a field rental feature for potential customers, as well as facilitates the processing of field rental data and financial report data for field owners.
\end{abstract}

Keywords: Futsal, Information System, PHP, Schedule, Web.

\section{PENDAHULUAN}

Futsal merupakan salah satu olahraga yang terkenal di Indonesia. Menurut (Ginanjar et al., 2017) Futsal atau yang dalam bahasa Spanyol adalah futbol sala, artinya sepak bola ruangan. Olahraga futsal identik dengan permainan team vs team dimana setiap team yang bertanding harus mempunyai 5 orang dimana yang terdiri dari 1 orang kiper dan 4 orang pemain. Salah satu dampak terkenal nya olahraga futsal di Indonesia adalah terdapat banyak sekali usaha seperti Penyewaan Lapangan Futsal. Menurut (Merdekawati et al., 2019) 
penyewaan lapangan futsal adalah sebuah usaha penyewaan yang menyediakan pelayanan jasa penyewaan lapangan futsal. Saat ini perkembangan tempat penyewaan lapangan futsal sudah semakin berkembang dengan cepat, hal tersebut dapat dilihat sudah semakin banyaknya tempat penyewaan lapangan futsal di berbagai daerah.

Salah satu contoh nya ialah pada tempat dilakukan nya penelitian ini, yaitu Ansha Futsal yang merupakan salah satu tempat penyewaan lapangan futsal di daerah Bekasi. Penelitian ini dilakukan karena Ansha Futsal masih menggunakan metode manual dalam proses pengajuan sewa lapangan, serta pendataan laporan penyewaan yang masih menggunakan pencatatan buku. Penelitian ini sangat penting dilakukan, karena untuk mengetahui dampak yang terjadi kepada calon pelanggan dengan metode penyewaan lapangan yang masih manual ini. Berdasarkan hasil penelitian yang dilakukan pada Ansha Futsal, metode penyewaan yang masih manual ini memberikan dampak masalah kepada calon pelanggan, yaitu ketika mereka sudah sampai di lokasi dan ternyata jam bermain yang diinginkan tidak ada, mereka akan merasa kecewa dan hanya membuang-buang waktu saja. Itu menyebabkan akan adanya penurunan minat bermain pada ansha futsal yang akan berdampak juga kepada berkurangnya pendapatan pemilik lapangan. Oleh karena itu akan dibuatlah sebuah Aplikasi Penyewaan Lapangan Futsal Berbasis Web, yang tujuannya adalah untuk mengatasi masalah para calon pelanggan ketika proses penyewaan lapangan. Aplikasi yang akan dibuat ini mencakup 3 aktor yaitu Admin, Pelanggan, dan Pemilik lapangan. Proses pengajuan akan dilakukan oleh pelanggan, kemudian akan memasuki proses approval oleh admin, dari sisi pemilik lapangan bisa melakukan cetak laporan.

Pada zaman modern seperti saat ini, suatu aplikasi akan sangat membantu seperti hal nya dalam pengajuan sewa lapangan. Aplikasi sangat berhubungan dengan Sistem Informasi, menurut (Sanawiah \& Hartiningsih, 2020) Sistem informasi adalah cara terorganisir untuk mengumpulkan, memasukan, memproses data dan menyimpannya, mengelola, mengontrol dan melaporkannya sehingga dapat mendukung perusahaan atau organisasi untuk mencapai tujuan. Sedangkan menurut (Anggoro \& Hidayat, 2020) Sistem informasi merupakan salah satu hasil pengembangan teknologi informasi yang banyak dimanfaatkan oleh organisasi untuk menjalankan kegiatan operasionalnya. Aplikasi pemesanan lapangan futsal berbasis web ini akan menyediakan fitur sewa lapangan dan sewa alat perlengkapan futsal. Aplikasi ini dibuat dengan basis Web. Menurut (Josi, 2017) Web atau Website adalah kumpulan dari halaman-halaman situs, yang terangkum dalam sebuah domain atau subdomain, yang tempatnya berada di dalam World Wide Web (WWW) di dalam internet. Sedangkan menurut (Destiningrum \& Adrian, 2017) web adalah Sebuah software yang berfungsi untuk menampilkan dokumen - dokumen pada suatu web yang membuat pengguna dapat mengakses internet melalui software yang terkoneksi dengan internet. Bahasa pemrograman yang digunakan ialah PHP, menurut (Maulana, 2014) PHP adalah bahasa pemrograman yang kodenya dijalankan disisi server, PHP juga merupakan bahasa pemrograman interpreter yaitu proses penterjemahan baris kode sumber menjadi kode mesin yang dimengerti komputer secara langsung pada saat baris kode dijalankan. Database server yang digunakan ialah menggunakan MySQL, menurut (Yuliansyah, 2014) MySQL adalah sebuah database manajemen system (DBMS) popular yang memiliki fungsi sebagai relational database manajemen system (RDBMS). Selain itu MySQL software merupakan suatu aplikasi yang sifatnya open source serta server basis data MySQL memiliki kinerja sangat cepat, reliable, dan mudah untuk digunakan serta bekerja dengan arsitektur client server atau embedded systems.

Sejumlah penelitian sebelumnya telah mengembangkan aplikasi atau sistem informasi berbasis web yang ada pada masing-masing organisasi, diantaranya adalah hasil penelitian 
oleh (Swastika \& Khasanah, 2017) yang dilakukan pada tempat futsal corner daerah Bekasi, penelitian itu memfokuskan kepada suatu hasil sistem informasi reservasi lapangan futsal yang bertujuan untuk memudahkan pihak lapangan futsal dalam pendataan pengajuan sewa oleh pelanggan. Sementara itu, hasil penelitian dari (Rahma, 2015) menjelaskan bahwa mereka telah menerapkan sebuah aplikasi penyewaan lapangan futsal untuk membantu petugas dan penyewa dalam melakukan penyewaan lapangan futsal. Berdasarkan hal itu, pada penelitian kali ini akan dibuat juga suatu aplikasi penyewaan lapangan futsal berbasis web yang bertujuan untuk mengatasi masalah yang terjadi pada ansha futsal ini. Yaitu suatu aplikasi dengan fitur utama pengajuan sewa dan adanya tambahan fitur yaitu pengajuan sewa alat futsal seperti sepatu dan kostum. Selain fitur pengajuan sewa lapangan futsal dan alat futsal, aplikasi ini juga menyediakan fitur laporan yang akan sangat membantu bagi pemilik lapangan futsal dari segi manajemen laporan keuangan, laporan sewa lapangan, serta laporan sewa peralatan. Dalam pengertian yang sederhana, laporan keuangan adalah laporan yang menunjukkan kondisi keuangan perusahaan pada saat ini atau dalam periode tertentu, laporan keuangan menggambarkan pos-pos keuangan perusahaan yang diperoleh dalam suatu periode (Rahmayuni, 2017).

Penelitian ini dilakukan bertujuan untuk mengatasi masalah yang terjadi pada latar belakang penelitian ini, yaitu merancang dan menghasilkan sebuah aplikasi penyewaan lapangan futsal yang lebih efisien dalam melakukan proses pengajuan sewa, serta memudahkan dalam pengelolaan data laporan penyewaan bagi pemilik lapangan futsal.

\section{METODE}

Metode yang digunakan pada penelitian ini terbagi menjadi dua, yaitu metode penelitian dan metode pengembangan. Metode penelitian difokuskan kepada Teknik pengumpulan data dan informasi untuk kebutuhan penelitian, sedangkan metode pengembangan dilakukan kearah langkah pembuatan aplikasi nya. Teknik Pengumpulan data dan informasi disini meliputi 2 cara, yaitu Observasi dan Kuesioner. Observasi dilakukan ketika para pelanggan melakukan penyewaan lapangan. Point penting dalam observasi ini adalah melihat bagaimana sistem penyewaan yang sudah ada pada lapangan futsal tersebut. Sedangkan tahap kuesioner ini dilakukan menggunakan Google Form yang ditujukan kepada calon pelanggan serta masyarakat umum lainnya yang pernah melakukan Olahraga futsal. Dari hasil kuesioner tersebut hampir $91 \%$ mengetahui bahwa metode penyewaan lapangan futsal tersebut masih manual, dan semua nya setuju jika ada nya Aplikasi Penyewaan Lapangan Futsal Berbasis Web.

Tahapan metode pengembangan pada aplikasi ini menggunakan metode Waterfall. Menurut (Muharto \& Ambarita, 2016) Metode waterfall ini memiliki ciri pendekatan yang sistematis dan urut mulai dari level kebutuhan sistem lalu menuju ke tahap analisis, desain, coding, testing/verification, dan maintenance. Tahapan awal dalam waterfall ialah analisis, Menurut (Jaya \& Sahlinal, 2017) pada tahapan ini dilakukan identifikasi masalah, studi literatur, menentukan spesifikasi kebutuhan perangkat lunak. Pada tempat penelitian ini dilakukan, ditemukan suatu masalah yaitu beberapa pelanggan yang ingin melakukan penyewaan lapangan tetapi tidak bisa dilakukan karena jadwal tersebut sudah terlebih dahulu disewa orang lain. Sehingga menyebabkan mereka harus mengganti jadwal yang ingin disewa atau bahkan berpindah ke tempat futsal lainnya. Berdasarkan masalah tersebut dapat di analisis bahwa dengan dibuatnya suatu Aplikasi penyewaan lapangan futsal berbasis web maka akan mempermudah penyewaan lapangan para pelanggan dimana saja dan kapan saja.

Pada tahapan desain aplikasi ini menggunakan software Balsamiq Mockups 3 untuk membuat tampilan user interface nya. Balsamiq mockups 3 merupakan software yang 
digunakan untuk pembuatan tampilan antarmuka pengguna atau user interface sebuah aplikasi. Software ini merupakan salah satu aplikasi yang banyak digunakan oleh para perancang aplikasi (Munawar et al., 2019). Dalam tahapan ini, dilakukan desain tampilan yang diharapkan mudah untuk digunakan pada semua kalangan umur. Setelah dilakukan desain, selanjutnya adalah masuk ke tahapan pengkodean / Coding. Tahapan pengkodean ini merupakan tahapan yang berkaitan dengan tahapan desain, tahapan ini menggunakan software Sublime Text sebagai script editor.

Selanjutnya dilakukan tahapan pengujian / testing. Dalam tahap pengujian ini dilihat apakah sistem dapat bekerja dengan baik, dan semua fungsinya bisa digunakan dengan baik dan lancar. Tahapan terakhir ialah Tahapan Maintenance, tahapan ini mengacu pada perbaikan atau melakukan update dari sebuah sistem aplikasi, serta pengembangan fitur fitur terbaru pada sistem tersebut. Menurut (Rambing et al., 2018) maintenance adalah tindakan menjaga sesuatu dalam kondisi operasi yang baik. Tahapan ini juga bisa dilakukan jika ada saran atau kritik dari pengguna aplikasi tersebut.

\section{HASIL DAN PEMBAHASAN}

\section{Hasil}

Berdasarkan penjelasan mengenai tujuan penelitian ini adalah untuk mengatasi proses pengajuan sewa lapangan futsal yang masih manual. Oleh karena itu solusi yang dihasilkan dari penelitian ini adalah dibuatnya sebuah aplikasi penyewaan lapangan futsal berbasis web dengan fitur utama yaitu pemesanan lapangan futsal. Pada gambar 1 dibawah ini merupakan tampilan Homepage atau Halaman Utama. Didalam nya terdapat gambar-gambar deskripsi lapangan, dan juga info detail tentang alur cara daftar, cara booking, serta cara pembayaran.

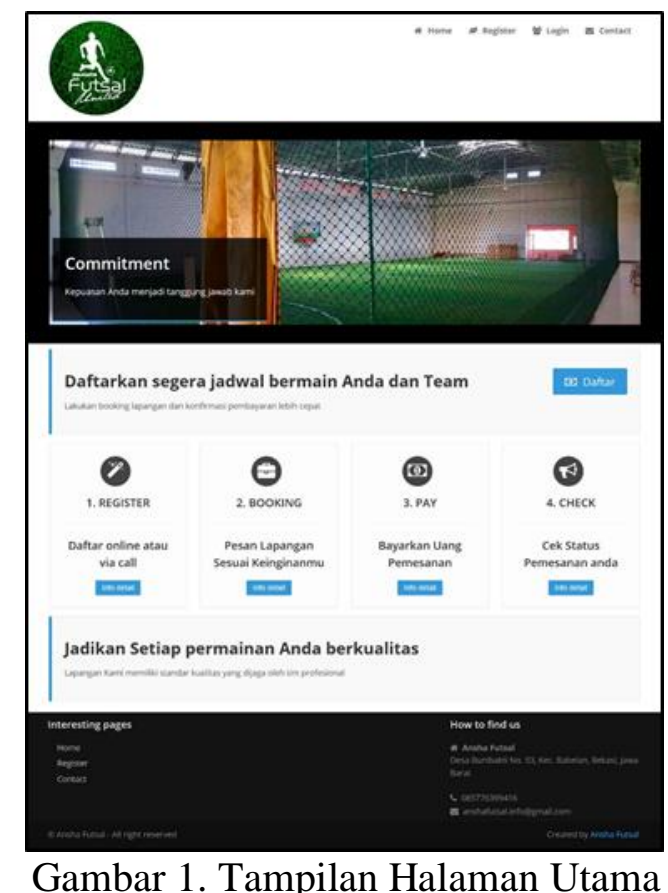

Pada gambar 2 merupakan halaman form register. Pelanggan melakukan isi data registrasi agar mendapatkan akun dan bisa login kedalam aplikasi. Setelah pelanggan melakukan register, maka bisa dilakukan login dengan mengakses menu login. Tampilan form login bisa dilihat pada gambar 3. 


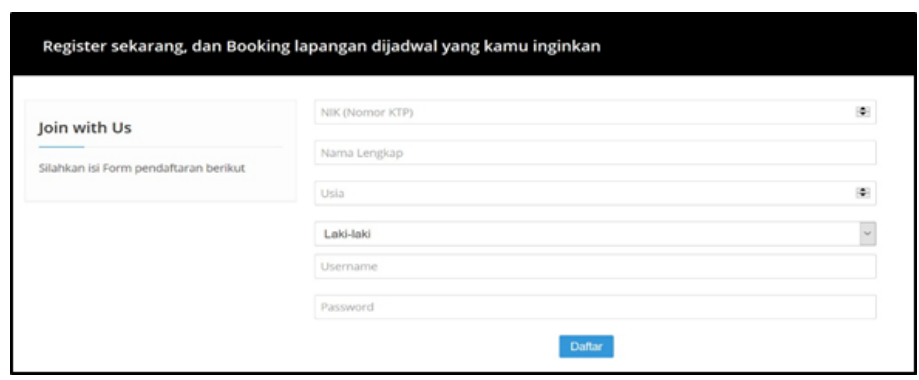

Gambar 2. Tampilan Form Register

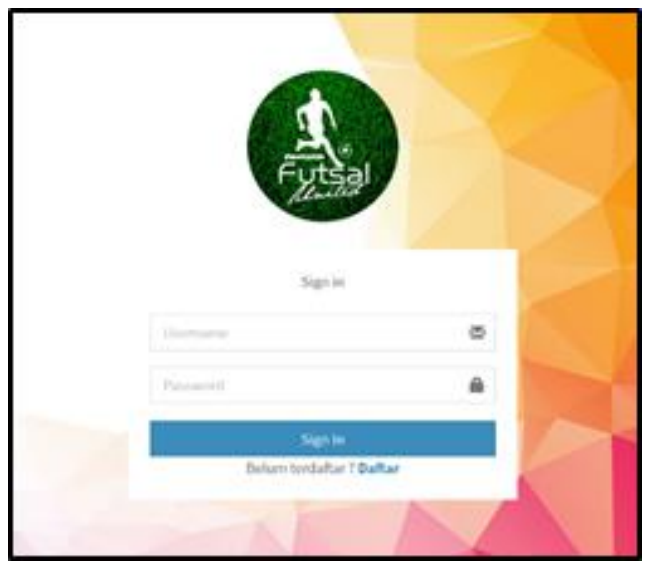

Gambar 3. Tampilan Form Login

Dapat dilihat pada gambar 4 dibawah ini merupakan halaman request booking lapangan. Pelanggan memilih jam bermain, jika ingin melakukan sewa sepatu atau kostum maka pilih menu sewa peralatan. Dapat dilihat bahwa Jam bermain berwarna biru menandakan sudah di Booking, Jam bermain berwarna hijau menandakan sedang ada permainan pada jam tersebut, Jam bermain berwarna putih menandakan jadwal masih kosong, dan Jam bermain berwarna merah menandakan jadwal sudah terlewat dan tidak bisa di booking.

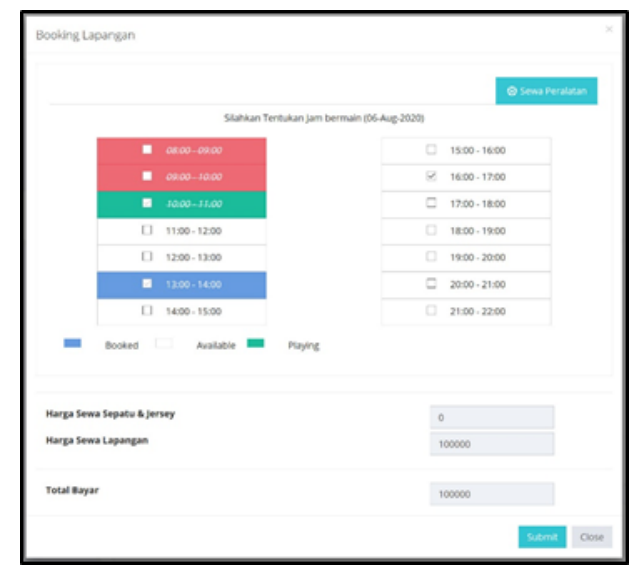

Gambar 4. Tampilan Request Booking Lapangan

Pada gambar 5 merupakan halaman untuk upload bukti pembayaran yang dilakukan oleh Pelanggan. Proses upload bukti pembayaran ini diberikan waktu 10 menit sejak jam pemesanan, jika dalam waktu 10 menit tidak dilakukan upload bukti pembayaran maka pemesanan lapangan akan otomatis batal. 


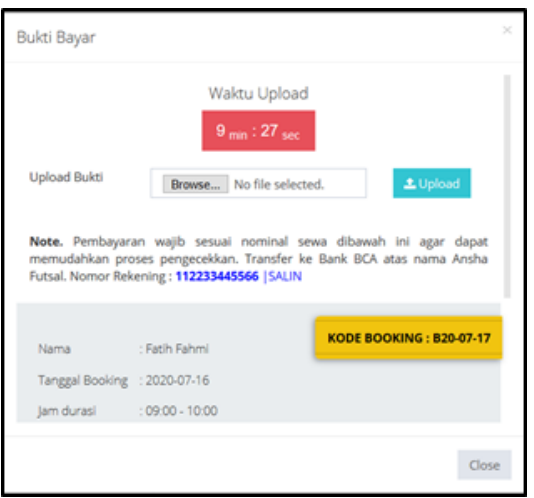

Gambar 5. Tampilan Upload Bukti Pembayaran

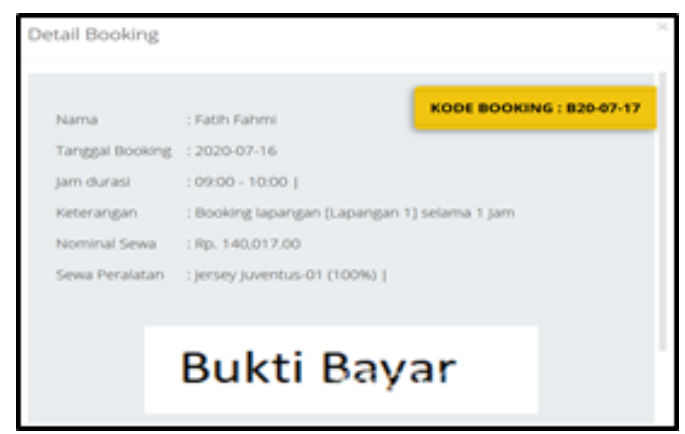

Gambar 6. Tampilan Detail Booking

Gambar 6 menunjukkan bahwa tampilan detail booking yang sudah di approve oleh Admin. Di dalamnya terdapat detail tanggal booking, durasi jam bermain, keterangan yang meliputi nama lapangan, total nominal sewa, detail peralatan futsal yang disewa, serta tampilan gambar bukti pembayaran. Pada gambar 7 merupakan ruangan chat yang dapat digunakan oleh pelanggan dan admin. Pada menu chat ini dapat digunakan oleh pelanggan seperti mengajukan pertanyaan seputar jadwal atau data booking kepada admin.

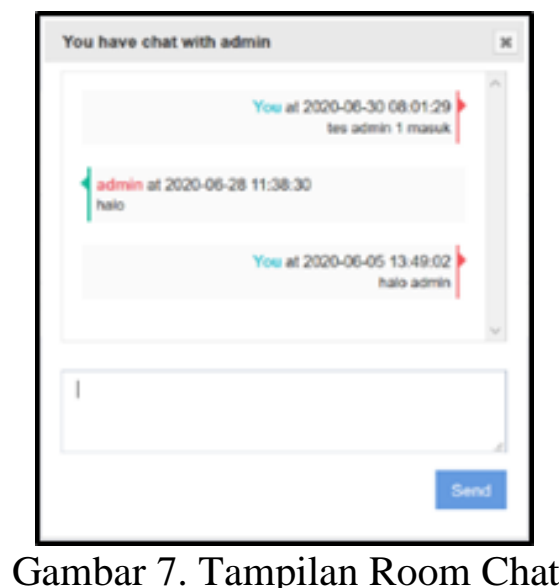

Gambar 7. Tampilan Room Chat 


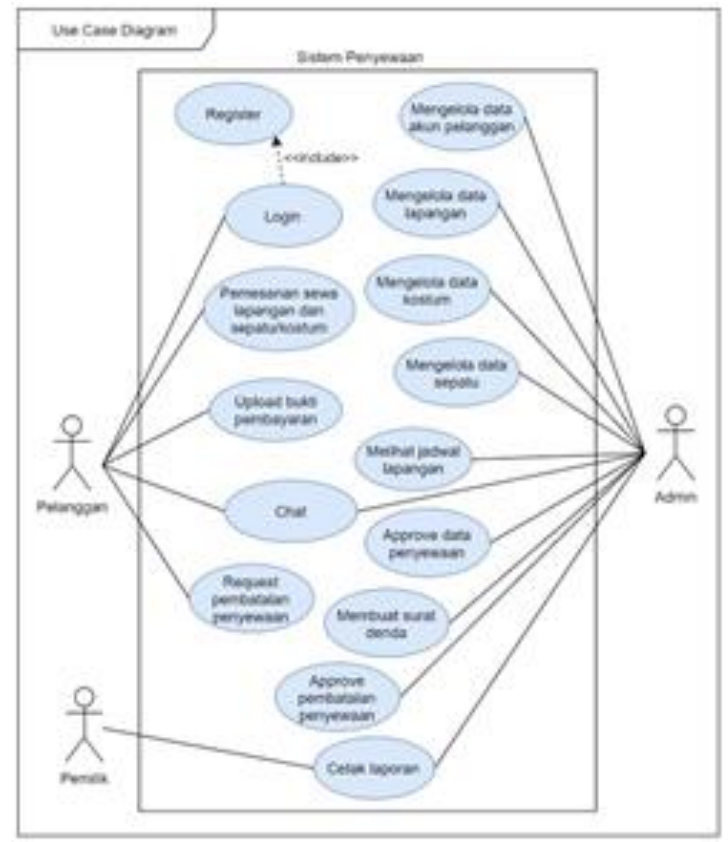

Gambar 8. Use Case Diagram

Pada Gambar 8 merupakan use case diagram dari Aplikasi Penyewaan Lapangan Futsal Berbasis Web ini. Pada use case ini pelanggan melakukan pengajuan sewa lapangan pada jam yang diinginkan. Lalu akan dilakukan proses Approve oleh admin. Sementara itu, Dapat dilihat pada gambar 9 merupakan hasil Class Diagram dari Aplikasi pemesanan sewa lapangan berbasis web ini, didalam database aplikasi ini terdapat 10 tabel yang saling berelasi. Sebagai contoh pada tabel trans_booking, didalamnya terdapat data yang meliputi data booking lapangan dan peralata, harga sewa, harga denda, data pembatalan, serta lampiran bukti pembayaran.

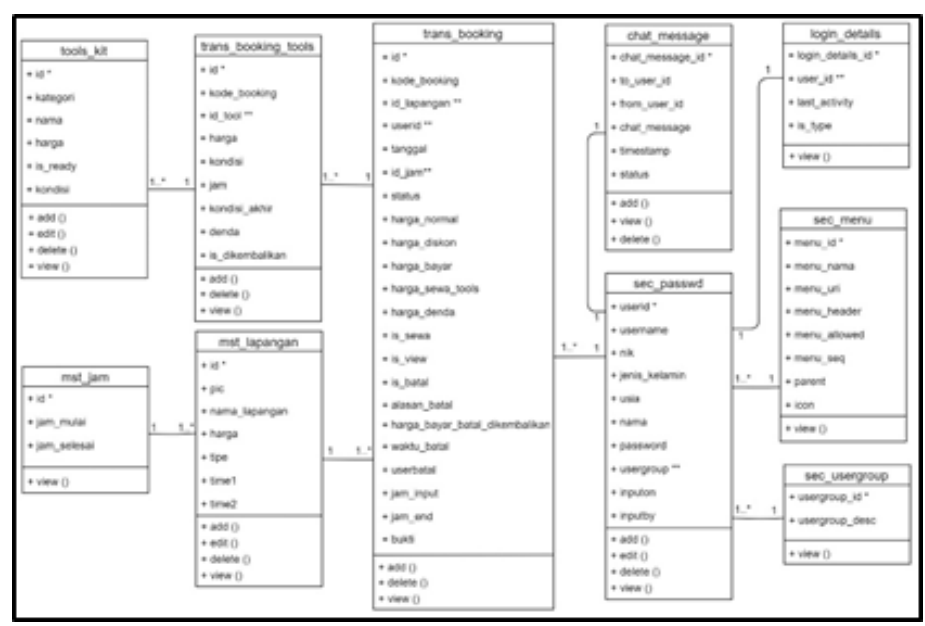

Gambar 9. Class Diagram

\section{Pengujian Aplikasi}

Tahap pengujian pada aplikasi ini menggunakan metode pengujian black box testing. Pada tahap pengujian ini difokuskan pada tampilan menu antar muka seperti Menu Register, Menu Login, Menu Request Sewa Lapangan, Menu Chat, serta Menu Laporan. 
Tabel 1. Hasil Pengujian Aplikasi

\begin{tabular}{|c|c|c|c|}
\hline $\begin{array}{l}\text { Komponen } \\
\text { Sistem }\end{array}$ & Butir Uji & Hasil yang Diharapkan & $\begin{array}{c}\text { Hasil } \\
\text { Pengujian }\end{array}$ \\
\hline $\begin{array}{c}\text { Halaman } \\
\text { Register }\end{array}$ & $\begin{array}{l}\text { Mengakses menu } \\
\text { register }\end{array}$ & $\begin{array}{l}\text { Menampilkan halaman } \\
\text { register }\end{array}$ & Berhasil \\
\hline $\begin{array}{l}\text { Halaman } \\
\text { Login }\end{array}$ & $\begin{array}{l}\text { Mengakses menu } \\
\text { Login }\end{array}$ & $\begin{array}{c}\text { Menampilkan halaman } \\
\text { Login }\end{array}$ & Berhasil \\
\hline \multirow[t]{7}{*}{$\begin{array}{c}\text { Menu } \\
\text { Request Sewa } \\
\text { Lapangan }\end{array}$} & $\begin{array}{l}\text { Mengakses halaman } \\
\text { request sewa } \\
\text { lapangan }\end{array}$ & $\begin{array}{l}\text { Menampilkan halaman } \\
\text { request sewa lapangan }\end{array}$ & Berhasil \\
\hline & $\begin{array}{l}\text { Button pemilihan } \\
\text { tanggal booking }\end{array}$ & $\begin{array}{c}\text { Menampilkan tanggal } \\
\text { booking }\end{array}$ & Berhasil \\
\hline & $\begin{array}{c}\text { Button Booking } \\
\text { Now }\end{array}$ & $\begin{array}{c}\text { Menampilkan jadwal } \\
\text { bermain sesuai tanggal } \\
\text { yang dipilih }\end{array}$ & Berhasil \\
\hline & Pilih jam bermain & $\begin{array}{l}\text { Menampilkan nominal } \\
\text { sewa lapangan }\end{array}$ & Berhasil \\
\hline & $\begin{array}{l}\text { Mengakses menu } \\
\text { sewa peralatan }\end{array}$ & $\begin{array}{c}\text { Menampilkan halaman } \\
\text { sewa peralatan jersey dan } \\
\text { sepatu }\end{array}$ & Berhasil \\
\hline & $\begin{array}{l}\text { Memilih jenis } \\
\text { peralatan (jersey } \\
\text { atau sepatu) }\end{array}$ & $\begin{array}{l}\text { Menampilkan list daftar } \\
\text { yang disewa beserta } \\
\text { kondisi alat tersebut }\end{array}$ & Berhasil \\
\hline & Button submit & $\begin{array}{c}\text { Data booking diajukan ke } \\
\text { pihak admin }\end{array}$ & Berhasil \\
\hline Menu Chat & $\begin{array}{l}\text { Mengakses menu } \\
\text { history chat }\end{array}$ & $\begin{array}{c}\text { Menampilkan menu } \\
\text { history chat }\end{array}$ & Berhasil \\
\hline \multirow[t]{5}{*}{$\begin{array}{l}\text { Menu } \\
\text { Laporan } \\
\text { Sewa } \\
\text { Lapangan }\end{array}$} & $\begin{array}{l}\text { Mengakses menu } \\
\text { laporan sewa } \\
\text { lapangan }\end{array}$ & $\begin{array}{l}\text { Menampilkan menu } \\
\text { pencarian periode } \\
\text { tanggal laporan dan } \\
\text { pemilihan jenis laporan }\end{array}$ & Berhasil \\
\hline & Isi periode tanggal & Tanggal terisi & Berhasil \\
\hline & Pilih jenis laporan & Laporan terpilih & Berhasil \\
\hline & Klik Button Cari & $\begin{array}{c}\text { Menampilkan laporan } \\
\text { sesuai jenis laporan yang } \\
\text { dipilih }\end{array}$ & Berhasil \\
\hline & Klik Button Print & $\begin{array}{l}\text { Menampilkan pop-up } \\
\text { untuk print dokumen }\end{array}$ & Berhasil \\
\hline
\end{tabular}

\section{Pembahasan \\ Hasil Produk}

Pada penelitian kali ini menghasilkan suatu aplikasi penyewaan lapangan futsal berbasis web yang lebih efisien dalam proses pengajuan sewa lapangan. Seperti yang terlampir pada gambar 1 sampai gambar 7 yang merupakan hasil tampilan menu antar muka pada aplikasi ini. Pada gambar 1 merupakan tampilan menu utama atau homepage ketika para actor (admin, pelanggan, pemilik) mengakses aplikasi tersebut. Pada gambar 4 merupakan tampilan ketika pelanggan ingin melakukan pemilihan jam bermain. Setelah melakukan pengajuan sewa, pelanggan bisa melakukan upload bukti pembayaran seperti pada tampilan gambar 5. Aplikasi ini dibuat menggunakan versi web dikarenakan web lebih mudah diakses, 
dan tidak perlu dilakukan suatu proses install. Dapat dilihat pada gambar 8 merupakan use case diagram yang memiliki 3 aktor yaitu pelanggan, admin, dan pemilik. Dan pada gambar 9 merupakan class diagram aplikasi penyewaan lapangan futsal berbasis web ini. Aplikasi ini telah melewati tahap pengujian, yaitu menggunakan metode black box testing yang bisa dilihat pada tabel 1 .

\section{Deskripsi Use Case Diagram}

Pada gambar 8 dapat dilihat bahwa use case diagram tersebut memiliki 3 aktor yaitu Pelanggan, Admin, dan Pemilik. Pada aktor pelanggan memiliki salah satu use case utama yaitu "Pemesanan sewa lapangan dan sepatu/kostum". Pada use case tersebut, aktor admin mempunyai peran dalam mengelola data lapangan, data kostum, data sepatu, dan data user/pelanggan. Aktor admin dan pemilik bisa melakukan cetak laporan yang meliputi laporan rekap keuangan, laporan data sewa alat futsal, dan juga laporan denda.

\section{Deskripsi Class Diagram}

Dapat dilihat pada gambar 9, terdapat 10 tabel yang saling berelasi. Pada tabel sec_passwd didalam nya menyimpan Data user/pelanggan. Terdapat juga tabel data master seperti tabel mst_jam yang mempunyai data master jam bermain, tabel tools_kit yang mempunyai data master tools/peralatan futsal, serta tabel mst_lapangan yang didalamnya terdapat data master lapangan. Pada tabel chat_message terdapat rekap data chat antara pelanggan dan admin, meliputi id chat, aktor chat, isi chat, serta waktu pada saat dilakukan nya chat tersebut.

\section{Hasil Pengujian}

Pada tabel 1 dapat dilihat bahwa telah disajikan data hasil pengujian aplikasi menggunakan metode black box testing. Metode ini dilakukan dengan cara mencoba menggunakan fungsi pada program dengan memasukan beberapa inputan ke dalam program kemudian memverifikasi hasil dari proses tersebut apakah sudah menghasilkan output yang diinginkan dengan fungsi yang sudah ditentukan. Berdasarkan tabel tersebut dapat dilihat bahwa semua hasil uji coba program berhasil dilakukan, uji coba aplikasi ini difokuskan pada akses terhadap menu antar muka seperti menu register, menu login, menu request sewa lapangan, menu chat, dan menu laporan sewa lapangan. Pada menu request sewa lapangan bisa dilihat bahwa telah dilakukan uji ketika pelanggan memilih jam bermain serta memilih peralatan futsal. Untuk pengujian menu laporan sewa dilakukan pada tahap pemilihan periode tanggal lalu memilih jenis laporan nya, serta melakukan cetak laporan. Hasil penelitian yang dilakukan oleh (Swastika \& Khasanah, 2017) pada Futsal Corner di Kota Bekasi menghasilkan sebah reservasi lapangan futsal yang mencakup ruang lingkup dari sisi admin saja, yaitu membantu mempermudah ketika admin melakukan pendataan pengajuan sewa oleh pelanggan. Sedangkan hasil penelitian oleh (Rahma, 2015) ialah sebuah aplikasi pengajuan sewa lapangan berbasis web dengan tambahan fitur sms gateway yang dapat memberikan info tentang status pengajuan sewa para calon pelanggan. Perbedaan yang terjadi antara penelitian terdahulu dan penelitian yang sekarang adalah untuk penelitian yang sekarang terdapat fitur menu pengajuan sewa alat futsal seperti sepatu dan kostum, fitur ini yang tidak ada pada penelitian sebelumnya.

\section{SIMPULAN}

Aplikasi sewa lapangan berbasis web ini dapat membantu para calon pelanggan yang ingin melakukan sewa lapangan futsal, karena aplikasi ini dapat diakses setiap saat sehingga menambah efisiensi waktu ketika ingin melakukan pemesanan. Tersedia juga fitur sewa alat futsal seperti Kostum dan Sepatu, sehingga membantu para calon pelanggan ketika ingin bermain tetapi tidak memiliki kostum atau sepatu. Dengan adanya aplikasi penyewaan lapangan ini maka akan meningkatkan daya tarik pelanggan untuk bermain futsal disini, karena metode penyewaan yang sangat mudah dan praktis. Itu juga akan berdampak pada 
bertambahnya angka pendapatan dari hasil sewa. Selain itu, pemilik lapangan futsal akan dimudahkan dengan adanya fitur laporan seperti rekap keuangan, laporan denda, laporan sewa lapangan dan alat futsal.

\section{REFERENSI}

Anggoro, D., \& Hidayat, A. (2020). Rancang Bangun Sistem Informasi Perpustakaan Sekolah Berbasis Web Guna Meningkatkan Efektivitas Layanan Pustakawan. Edumatic: Jurnal Pendidikan Informatika, 4(1), 151-160.

Destiningrum, M., \& Adrian, Q. J. (2017). Sistem Informasi Penjadwalan Dokter Berbassis Web Dengan Menggunakan Framework Codeigniter (Studi Kasus: Rumah Sakit Yukum Medical Centre). Jurnal Teknoinfo, 11(2), 30-37.

Ginanjar, G. A., Budiman, E., \& Pohny. (2017). Sistem Informasi Olahraga Futsal Kutai Kartanegara Berbasis Web. Prosiding SAKTI (Seminar Ilmu Komputer Dan Teknologi Informasi), 2(1), 353-358.

Jaya, T. S., \& Sahlinal, D. (2017). Perancangan Kantor Digital Berbasis Framework dengan Metode Waterfall pada Politeknik Negeri Lampung. Jurnal Pengembangan IT (JPIT), 2(2), 14-17.

Josi, A. (2017). Penerapan Metode Prototyping Dalam Membangun Website Desa (Studi Kasus Desa Sugihan Kecamatan Rambang). Jurnal Teknologi Informasi Mura, 9(1), 5057.

Maulana, M. S. (2014). Perancangan Dan Pengembangan Aplikasi Web Penjualan (Studi Kasus : CV. Herson Mitra Solusindo). Jurnal Khatulistiwa Informatika, 2(2), 175-183.

Merdekawati, A., Rahayu, L. K., \& Yulianti, W. (2019). Sistem Informasi Penyewaan Lapangan Futsal Berbasis Web Pada Futsal Station Bekasi. Jurnal Pendidikan Teknologi Dan Kejuruan, 16(1), 21-32.

Muharto, \& Ambarita, A. (2016). Metode Penelitian Sistem Informasi: Mengatasi Kesulitan Mahasiswa dalam Menyusun Proposal Penelitian (1st ed.). Deepublish.

Munawar, Z., Fudsyi, M. I., \& Musadad, D. Z. (2019). Perancangan Interface Aplikasi Pencatatan Persediaan Barang Di Kios Buku Palasari Bandung Dengan Metode User Centered Design Menggunakan Balsamiq Mockups. Jurnal Informatika, 6(2), 10-20.

Rahma, A. N. (2015). Aplikasi Penyewaan Lapangan Futsal Berbasis WEB dan SMS Gateway. Jurnal E-Proceeding of Applied Science, 1(1), 663-668.

Rahmayuni, S. (2017). Peranan Laporan Keuangan dalam Menunjang Peningkatan Pendapatan Pada UKM. Jurnal Sosial Humaniora Dan Pendidikan (JSHP), 1(1), 93-99.

Rambing, Y. F., Wikarsa, L., \& Sanger, J. B. (2018). Rancang Bangun Aplikasi Reminder Maintenance Aset Berbasis Web. Jurnal Lasallian, 13(1), 55-63.

Sanawiah, S., \& Hartiningsih, W. B. (2020). Sistem Informasi Verifikasi Dan Validasi Penempatan Jabatan Pelaksana Pada Pemerintah Provinsi Dki Jakarta. 11(1), 50-56.

Swastika, R. H., \& Khasanah, F. N. (2017). Sistem Informasi Reservasi Lapangan Futsal Pada Futsal Corner Menggunakan Metode Waterfall. Jurnal Mahasiswa Bina Insani, 1(2), 251-266.

Yuliansyah, H. (2014). Perancangan Replikasi Basis Data Mysql Dengan Mekanisme Pengamanan Menggunakan SSL Encryption. Jurnal Informatika, 8(1), 826-836. 